\title{
The Influence of Students' Attitudes to Students with Special Needs
}

\author{
Hayatun Thaibah, Mirnawati, Indah Permata Sari \\ Special Education Program \\ Universitas Lambung Mangkurat \\ Banjarmasin, Indonesia \\ hayatun.thaibah.plb@ulm.ac.id, mirnawati.plb@ulm.ac.id, indahpermatasari23@gmail.com
}

\begin{abstract}
The purpose of the study was to determine the effect of students' attitudes on students with special needs in the Special Education Study Program of the Teaching and Education Faculty at LambungMangkurat University in Banjarmasin. This research used descriptive research with a quantitative approach. The research sample was the third-semester students who were registered as students of the Special Education Study Program of the Teaching and Education Faculty at Lambung Mangkurat University in Banjarmasin as many as 68 students. Data collection technique was a scale. The scale used in this study was closed questions. The data was analyzed by using KolmogorovSmirnov. The results showed that there was a significant influence on students' attitudes towards students with disabilities, with the Kolmogorov-Smirnov value was 0.996 . It can be concluded that the attitude of regular students towards students with special needs is very significant. The next researcher is expected to conduct a study by connecting with other variables or with experimental research models so that researchers can become direct participants in following all activities carried out by students with special needs with regular students.
\end{abstract}

Keywords - student attitudes, students with special needs.

\section{INTRODUCTION}

Every human being has the right to education including people with disabilities. At the beginning of education for people with disabilities, special schools appeared according to their classification, called separate schools or segregation schools. As time passed by and the development of people with disabilities become more rapidly, the education of people with disabilities progressed. People with disabilities get the same rights as attending regular schools called inclusive education. Education is a conscious effort to prepare students through guidance activities, teaching or training and good service for its role in the future. Rules about the importance of someone in terms of education are listed in UUD 1945 chapter 31 verse 1 which reads: "Every citizen has the right to get teaching". The article explains that all citizens without exception children with special needs are entitled to receive educational services according to their ability, talents, interests and learning needs. People with disabilities or in the world of Special Education commonly referred to as children with special needs are children who in the process of growth or development significantly experience abnormalities or deviations (physical, mental-intellectual, social, emotional) compared to other children of their age.
About special education and special education services in tertiary institutions 1 paragraph 1 and 2, "Special Education is an educational service for students with special needs in higher education. And special service education is the implementation of education in universities for students from the leading regions, outermost, and left behind, as well as students who experience natural disasters, social disasters, and are economically incapable". The process of education in higher education will be effective and have a significant impact on the process of change and development if seen by measuring the performance of both the process and the product. Students are the parties who use the assessment results at a college. Students can learn about their performance and learn their performance quality standards based on the results of their lecturers' assessment for each subject [1]. They are human beings who are included in the late adolescent period towards the adult period. The development stage towards the adult period, students need to prepare themselves by developing one of the characteristics for the ability to think adults that are thinking critically.

Children with disabilities are recognized for their existence and therefore special schools, nursing homes, social institutions that specifically educate and care for children with disabilities are starting to be established. Students with disabilities are considered to have special characteristics and are different from most (normal) people so that in their education requires very specific approaches and methods in accordance with their characteristics. Therefore education for children with disabilities must be separated (in special schools) from normal children.

Ref. [2] defines children with special needs as a child who has differences in several dimensions of humanity, namely physical, intelligence, and social-emotional that does not function, thus inhibiting his/her humanitarian functions, such as deafness, blindness, speech disorders, physical disabilities, mental retardation, and emotional disturbances. Ref. [3] explained the child with special need from the point of education is different from students in general. Various barriers are presented both mentally and learning disabilities because it is difficult to focus on one thing, social and emotional disturbances, limitations in communication, physical, hearing, vision, autism and special intelligent and special talents. This difference is the need education must be specifically, by considering several things such as the 
character of the needs of each the child with special need student.

As time passed by and the development of children with disabilities which were increasingly rapid, the development in developing the potential that can be developed and even that potential can exceed normal children. Understanding of the right of every child in education to have no equal discrimination, including for persons with disabilities, the eyes of the world are increasingly open about the education of persons with disabilities so that the potential of disability sufferers can develop. Inclusive education emerges, where children with disabilities have the right to receive education services in regular schools with friends of their age. This educational model seeks to provide equal opportunities to all children including disability adversaries to obtain equal learning opportunities, equal access both from learning resources and infrastructure in optimizing the potential of persons with disabilities.

The implementation of inclusive education involves various parties to be able to benefit maximally. Inclusive education in its implementation requires the involvement of schools, communities, and families. The community starts from the highest level of policy makers, and the environment around children and industry as a place for children to explore the potential after learning. The family is very much needed material and nonmaterial support to support the continuity of learning.

A mental and neurological state of readiness, which is governed by experiences that have a dynamic or direct influence on individual responses to all objects and situations associated with it [4]. Attitude is defined as an order in terms of thinking (cognitive), feeling (affective) and the tendency to behave (psychomotor) a person towards a psychological object.

According to [6] research, there is a negative relationship between the attitudes of regular students to students with special needs and the tendency of bullying, namely $(r=-$ 0.234: $p=0.000: p<0.01)$. The more negative the attitude of regular students towards students with special needs, the higher the tendency of bullying behavior and vice versa. The results showed that $25 \%$ of classroom teachers had very good attitudes towards children with special needs, $70.83 \%$ of classroom teachers have attitudes towards children with special needs in good categories, $4.17 \%$ of classroom teachers have attitudes towards children with special needs in very bad categories. The attitude of classroom teachers towards children with special needs in inclusive primary schools is on average in the good category of 220.92. Teachers who have attitudes towards children with special needs have good categories of knowledge, beliefs, and views related to children with special needs.

The results of the research conducted in [7] show that students have a favorable attitude or agree to the use of discussion on controversial issues. This attitude is directed to aspects of knowledge of controversial issues, the suitability of the discussion method with the development of critical thinking, the role of the lecturer, student participation, problem-solving and the benefits of discussion.
The results of the research conducted in [1] showed that one of the efforts considered to be able to improve students' honest attitude in assessing their strengths and weaknesses in learning is through self-assessment. Self-assessment is an assessment technique that students are asked to assess themselves in relation to the status, process and level of achievement of the competencies learned in certain subjects based on established criteria. The results of self-assessment will determine the competencies possessed by students and will certainly be directly proportional to changes in attitudes in assessing each student by assessing himself honestly and objectively. Conversely, if students judge is not honest and objective, the implementation of student tendencies will occur here so that the principles of assessment will be violated and as a result, the results of the assessment will be biased and not reflect the actual results.

The results of the research conducted by [8] showed that most of the students have a good knowledge of as many as 86 people $(86 \%)$ and having a positive attitude as many as 59 people $(59 \%)$, and most respondents reproductive care measures by $52(52 \%)$. The result of the chi-square test indicates that the attitude and knowledge with treatment action to reproductive organ have the same value that is $p=0.006$. It is concluded that there is a significant relationship between knowledge and treatment action of the reproductive organ with OR 8,33 (95\% CI: 1,75-39,54) and also there is a significant relation between attitude an treatment action of the reproductive organ with $\mathrm{OR}=3,49(95 \% \mathrm{CI}: 1,51-8,06)$.

The results of the research conducted by [9] show there were three treatment groups which are - two experimental groups (behavioral objective-based (group 1, N=117) and study question-based (group II, $\mathrm{N}=95$ ) instructional strategies and a control group (group III, $\mathrm{N}=100$ ). A total of 312 students' were involved in the study. The classrooms were randomly selected in each school and all the students' in the selected classroom constitute the sample (intact class). Students' Attitude Questionnaire (SAQ) has a reliability coefficient of $r=0.81$. Findings revealed a significant effect of treatments (BOBIS \& SQBIS) on students' attitude towards mathematics.

The results of the research conducted by [10] show that students' attitude toward the subjects of Physics-Mathematics II for 3 indicators is included in the attitude of good enough.

The results of the research conducted by [11] show most students' in the treatment group got $55 \%$ or sufficient category in the pre-test and $90 \%$ or high category in post-test. From the Marginal Homogeneity analysis of treatment group's pre- and post-test on the level of knowledge, it was found that P-Value 0.007 ( $\alpha=0,05)$. In the control group, the pre-test was $50 \%$ or insufficient category and the post-test was $90 \%$ or sufficient category. From the Marginal Homogeneity analysis of control group's pre- and post-test on the level of knowledge, it was found that the P-Value is $0,004(\alpha=0,05)$. The treatment group's attitude in the pre-test was $95 \%$ or in the positive category and the post-test was $100 \%$ or in the positive category with MCNemar's analysis of P-Value 1,000 ( $\alpha=0,05)$. In the control group, the pre- and post-test were the 
same $(90 \%$, in the positive category) with McNemar's analysis of P-Value $1.000(\alpha=0,05)$.

Based on the observations conducted at the Special Education Study Program, Universitas Lambung Mangkurat Banjarmasin, there are some people with disabilities who follow advanced education to college. People with disabilities want to get the same learning as normal children, want to develop their potential and reach their goals. In addition to wanting to get a degree and reach goals, people with disabilities also want to develop and feel how to occupy the lecture bench. They claim that they can certainly even be more than normal children, even though we experience obstacles, this obstacle does not become an obstacle for us to develop and become a pride for everyone". These people with disabilities are majoring in Special Education. Referring to the data above, the researcher is interested in expressing the attitude of Special Education Students towards Disabled Persons in the Special Education Study Program at the University of LambungMangkurat in Banjarmasin.

Attitudes have the characteristics of certain objects and contain an assessment. Ref. [12] argues in the opinion of Warren, Cantril, Baldwin, and Allport that attitude is a disposition or predisposition to react and attitudes as a function of readiness to function.

The definition of attitude is divided into three groups of views. The first group was represented by Thurstone, Linkert, and Charles Osgood, that according to the attitude towards the object is a feeling of support or partiality or a feeling of not supporting or not taking sides with the object of the attitude [13]. Thurstone further explained that attitudes are "a tendency for the degree of positive affect or negative affect to an object of psychology" [14]. The opinion of Thurstone, Likert and Osgood is that the attitude has direction.

The second group was represented by [14] who thought the attitude was "an anticipative pattern of behavior, tendencies or readiness, predisposing to adjust to social situations". Ref. [15] argues "attitude is a mental and nervous state of readiness, which is regulated through experience that has a dynamic influence or directed towards an individual's response to all objects and situations associated with it". Simply put, attitude is a response to social stimulation. This opinion emphasizes the form of self-adjustment in social situations and is further elaborated in the structures that make it up. The third group has a tendency to triadic schemes. Secord \& Backman defines attitude as a particular order in terms of thinking (cognition), feeling (affection), and the tendency of a person's (psychomotor) actions towards an aspect in the surrounding environment [14]. Based on the discussion of the attitude definition of the three groups, the researcher is more inclined to the definition of attitude referring to the concept of triadik. Where attitude is formed by three components namely cognitive, affective, and psychomotor which is a form of reaction to a person's interaction with a psychological object.

Attitude is defined as an order in terms of thinking (cognitive), feeling (affective), and the tendency to behave (psychomotor) someone towards a psychological object. The attitude referred to in this study is the attitude of teachers formed from cognitive, affective, and psychomotor components when facing psychological objects in the form of children with special needs. This attitude is in the form of a pattern that appears regularly and is justified by cognitive, affective, and psychomotor aspects. Attitudes have direction and depth.

Ref. [14] said the attitude formation structure included cognitive components, affective components, and psychomotor components. The cognitive component is limited to containing one's beliefs about what is valid or what is right for the object of attitude. The affective component concerns the subject of one's subjective emotional attitude toward the object. Psychomotor components show the tendency to behave in a person towards the object of attitude faced. Ref. [15] argue that the cognitive component is one's beliefs about an object based on perceptions of facts. In line with this understanding, Ref. [16] provides an understanding of cognitive components which are related to "knowledge, views, beliefs, namely things related to how people perceive objects of attitude". Both opinions provide an understanding of the cognitive component as a belief, knowledge, view, and one's perception of the object of attitude.

Affective components are also called emotional components. Ref. [16] provides additional affective components related to feelings of pleasure and dislike. This opinion shows that the affective component is a component related to feelings and has direction. Psychomotor components in the attitude structure show how the tendency of a person behaves towards an object of attitude. This is as stated by [13] that the tendency of one's behavior is influenced by beliefs and feelings towards an object of attitude. The same opinion was expressed by [15] that components related to the tendency to behave are based on observations or one's understanding of an event related to the object of attitude.

The attitude pattern of an individual is formed by a reaction to various psychological objects. Attitude formation in social humanitarian interaction is influenced by several factors. The factors of formation and change of attitude are influenced by internal factors and external factors. Internal factors are factors that come from within the individual. Internal factors are the power of a person to receive and process influences that come from outside [17]. Internal factors in a person can be in the form of emotions, experiences, and others.

Here are some factors that fall into the category of internal factors that influence attitudes. Personal experience is one of the foundations that influence appreciation of a psychological object. Experience is the result of natural contact with the human senses [18]. The experience gained by the five senses of man becomes a source of knowledge in the form of tools to lift objects from outside the human self through sensory functions [19]. The experience of an object makes humans have knowledge. Knowledge has a meaningful relationship with individual attitudes toward an attitude object [20].

Thus experience can influence the attitude of an individual because experience produces knowledge and has a relationship with attitudes towards an object of attitude. Personal experience related to psychological objects usually affects the 
direction of the individual's attitude [13]. Individuals who do not have any experience related to objects usually have a bad attitude towards psychological objects.

Experience involves observing and interpreting and interpreting in depth so that it becomes a choice of an object [21]. The experience that is able to influence attitudes is an experience that is able to give meaning to an individual. Emotions within oneself can affect an individual's attitude towards an object of attitude. Emotion is a tendency to have certain feelings when dealing with an object of attitude that functions as an inner adjustment to achieve individual welfare and safety [12]. According to several studies, emotional intelligence affects individual attitudes toward certain attitudinal objects [22]. Ref. [23] argue that influential emotions are examples of channeling frustration or transferring the ego defense mechanism. Emotions are usually only temporary, but can also last a long time. The tendency of someone who is dominated by positive emotions can show intelligence in behaving positively towards others. Even the intelligence of managing emotions can affect others who indirectly have emotional ties.

External factors are factors that come from outside an individual. As the opinion of [17] which states that external factors are factors that come from outside the individual. External factors that influence a person's attitude towards an attitude object are presented below. The influence of other people who are considered important usually affects a person's attitude. This is usually because someone does not want to conflict with people who are considered important [13]. Other people who are considered important can be close friends, peers, teachers, co-workers, parents, superiors and others. The influence given by a leader is done to shape the attitude of his subordinates as expected by the leader [24]. This influence is followed because ordinary people have an imitation attitude or follow those who have the authority or who are trusted.

Regarding the influence of culture, [14] said that culture has instilled a line of directing our attitude towards various problems. Individuals who adhere to regularity and respect for cultural traditions will foster an attitude that is already established compared to creative attitudes towards a problem or innovation [25]. Only established individuals can influence culture.

Another word of attitude that a person has is influenced by the cultural conditions in the person's environment. In accordance with social learning theory, where people learn is influenced by their environment and culture. The mass media, in their duties as information carriers, also carry suggestive messages to direct one's opinion [13]. The mass media is a "communication tool for many people" [26]. Information and strong suggestive messages are the cognitive and affective basis for someone to behave. Information and suggestive messages that will both influence cognitive and affective attitudes to become positive. The foundation for justifying a behavior based on the information it has.

Institutions or educational institutions and religious institutions become the basis for someone to behave because in these institutions "laid the foundation of understanding and moral concepts for individuals" [13]. Institutions or organizations want to achieve organizational goals by planting new attitudes [24]. Planting a new attitude from the organization to the individual in it is expected to have an impact on the individual's behavior and disseminated to others in the organization. The moral concept is instilled in human beings through education informally, nonformally or formally, thus forming an attitude pattern that is embedded in an individual human being. Educational institutions that actually become a miniature of the future, are closely related to the views of people related to the future they have and face.

The attitude according to [14] has special characteristics or dimensions. These characteristics include dimensions of direction, dimensions of intensity, dimensions of breadth, dimensions of consistency, and dimensions of spontaneity. Attitudes have a positive direction and a negative direction[13]. Positive direction occurs when attitude leads to agree, support or side with a psychological object. A positive attitude can be interpreted as a good attitude towards a psychological object, while a negative direction occurs when an attitude leads to disagree, does not support/reject, and does not take sides with the psychological object they are facing. Negative attitudes can be interpreted as a bad attitude towards a psychological object.

Attitudes have intensity, meaning "the depth or strength of the pressure of attitude towards something psychological object is not necessarily the same even though the direction is not different" [13]. According to [28] intensity is a force that supports an attitude or opinion. Someone's response to a psychological object is that there is an extreme degree of someone who just agrees. The degree of difference is a different level based on conditions and decisions taken by someone in facing a psychological object.

Attitude has broadness, meaning "agreement and disagreement of an object can be reached by individuals with other individuals differently" [13] For example, there is someone who agrees with all aspects of the implementation of inclusive education, but there are people who only agree on some agreed parts in the implementation of inclusive education, so that differences can be found when exploring the attitude of one person with another, caused by different backgrounds between individuals.

Attitudes have consistency, the meaning is the suitability of attitudes between the attitude statements expressed with the intended attitude response [13]. Attitude consistency is evidenced by the long-term suitability of the attitude. A consistent attitude can change in the opposite direction because the components are mutually supportive [12] If the attitude shown is easy to change, it is called an inconsistent attitude. However, when there is a difference between cognitive and affective there will be an adjustment that makes the two aspects come back in line and in agreement, resulting in a relatively long consistency.

Attitudes have the characteristics of spontaneity, namely how far the readiness of individuals in expressing their attitude spontaneously [13]. The attitude is said to have high spontaneity if, in its disclosure, it is carried out openly without prior pressure so that the individual will express it. The 
attitude that arises spontaneously is more valuable as an individual's original attitude.

Based on some expert opinions about attitudes, it can be concluded that attitude is a reaction or response in the form of an assessment that arises from an individual to an object. Attitudes can also be said as an embodiment of awareness of the environment. The process that initiates the formation of an attitude is the presence of objects around the individual providing a stimulus which then concerning the individual senses, the information captured about the object is then processed in the brain and raises a reaction. An appraisal that appears, positive or negative is influenced by previous information or individual personal experience.

Children with special needs are those who because of a special need for special education services so that their potential can develop optimally. The concept of children with special needs has a broader meaning and scope than the concept of extraordinary children [27]. Children with Special Needs are those who have temporary or permanent special needs so that they need more intense educational services [28].

Children with Special Needs are another term to replace the word "Extraordinary Child" which indicates a special disorder. The word "Children with Special Needs" is used to refine the connotation of the meaning of children with disabilities. Children with special needs have different characteristics between one another [29]. Children with special needs require a special learning method. A varied pattern of motion is believed to increase the potential of students with special needs in learning activities related to the formation of physical, emotional, socialization, and reasoning [30]. Ref. [3] argue that students with special needs are anyone who needs special education and appropriate services to maximize their humanitarian potential. Basic concepts related to students with special needs have two important things, (1) differences in characteristics and (2) requires special education [3].

So, Children with Special Needs are children who have different characteristics in the ability to see, hear, think and adapt, physical and health, emotional and social, specific learning, autistic, or giftedness, which have an impact on special needs in education and services related to education.

Vision impairments are limited as people who experience obstacles in receiving information by using the sense of sight [31]. The child is said to have vision problems if the vision is less than $6 / 21$. This means that when tested, the child is only able to read letters at a distance of 6 meters which the alert person can read at a distance of 21 meters. Visual impairments can be divided into two, (1) Total blindness and (2) Low vision. It is said to be totally blind when the child is unable to see at all (vision 0), only able to distinguish dark light. It is said to be a low vision when children are still able to receive light stimuli from outside but their sharpness is more than $6 / 21$ [31]. Ref. [3] suggested that included in people with visual impairment are those who have the ability to see 20/200 or less even though they have used visual aids, or have limitations in viewing angles that are only able to see no more than 20 level. This special condition in vision is the basis for providing assistance in the field of education. This form of assistance can be in the form of replacing methods or media that previously tend to be visually directed to the auditory and tactile. It aims to maximize the ability possessed in the field of auditory sensory reception and sensory sensation. But for students who experience visual impairment low vision can maximize the remaining vision by using visual media with a large size or enlarged with a magnifying glass.

Hearing impairment is divided into two, namely deaf and hard of hearing. Deaf is a condition of hearing disability that affects auditory language skills, either with help or without the aid of hearing aids, while people with Hard of Hearing are people who have hearing impairments, but when given hearing aids are able to communicate or use auditory language [3]. Ref. [31]defines children with hearing loss as those who have hearing loss in part or entirely which causes hearing to have no functional value in everyday life. This definition is the basis for individuals to obtain special services in education. The lack of conditions in the auditory requires the child to be able to understand the environment visually or tactically so that the media and methods used in accommodating learning are internalized through visual knowledge and not only with lectures that use auditory.

The definition of intellectual impairment and development follows the definition AAMR[3] is an inability that has the characteristics of limitations in the functions of intelligence and adaptation ability shown in conceptual, social and adaptation skills and these obstacles begin before age 18 years. AAIDD (American Association on Intelectual and Developmental Disabilities) in Hallahan, et al[3] underlined in two respects: (a) intellectual barriers affecting adaptive behavior are not only limited to intellectual functions, and (b) intellectual functions and adaptive behaviors of an intellectual barrier can be developed.

Ref. [31] mentions children who experience intellectual and developmental barriers as mentally retarded people who are conditions in which intelligence development experiences obstacles so that they do not reach an optimal stage of development. Children with intellectual and developmental disorders are limited to children who during developmental times have problems adjusting their behavior or adaptation and have intellectual abilities below average (IQ below 70 binary scales) [31]. The definition of barriers that center on the ability to think is intended to think abilities that are below the average level make students need help in understanding learning. Problems in learning, also affect the problem of student adaptation to the environment so that incapacitating tendencies appear because of very striking differences between individuals with intellectual impairments and adaptation. The adaptation given can be in the form of a decrease in standards given to students in obtaining learning and must maximize the overall sensory and motor senses possessed.

Children with physical and health disorders are those who have physical limitations or health problems that interfere with school or study activities until they need services, training, equipment, materials, and facilities specifically [3]. Meanwhile, [31] defines children with physical disorders as "conditions that inhibit individual activities as a result of 
damage or disruption to the bones and muscles thereby reducing the normal capacity of individuals to attend education and to stand alone". The general definition of this condition is the special needs displayed in physical conditions and the health condition of a person so that it affects the child's condition in learning in general as the child physically does not experience problems.

Treatment can be given with problematic organ maximization to be able to function optimally or for those who have problems to develop their abilities, can be directed to use an organ that functions and allows it to be developed as a substitute. For example, for children who experience hand paralysis, the difficulty in writing can be replaced by feet. However, if there is still potential to be used, hands that are paralyzed can be given therapy for potential activities.

Children with special needs are children who experience physical, social, emotional, behavioral, intellectual barriers so that they influence learning and need assistance specifically in the field of education. The emergence of the concept of inclusive education that provides facilities for children with special needs to be able to obtain a proper education in public school institutions.

This study aims to find out how the attitude of regular students towards students with special needs in the Special Education Study Program of the Teaching and Education Faculty of LambungMangkurat University in Banjarmasin.

\section{METHOD}

This study used a descriptive type of research with a quantitative approach that aims to reveal things as they are. Redf. [32] revealed that descriptive research is not intended to test specific hypotheses, but only describes what it is about a variable.

The subjects of this study were regular students of the third semester of the Special Education Study Program in the Faculty of Teacher Training and Education, Lambung Mangkurat University in Banjarmasin as many as 68 people.

The measuring instrument used in this study is an attitude scale based on the notions put forward by Secord \& Backman namely certain regularities in terms of thinking (cognition), feelings (affection) and the tendency of actions (psychomotor) a person towards an aspect in the surrounding environment [14].

The method used in data collection to measure attitudes towards students with special needs uses the attitude scale of regular students towards special needs students who reveal 3 aspects, namely: (1) cognitive aspect that is beliefs about what applies to the object being addressed, (2) affective aspect namely linking subjective emotional in addressing an object, and (3) psychomotor aspect is the result of a behavior or just a tendency to behave in relation to assumptions on emotional beliefs and feelings. The scale of the attitude of regular students towards students with special needs must also be tried out to determine the validity of items on a scale.

The procedure in the first research is the preparation stage, namely the preparation stage of the Likert scale. For the scale of the attitude of regular students towards students with special needs is made based on aspects that exist in attitude according to [14]. The second stage is looking for relevant research locations, namely, universities that run the inclusion program and the target subject of the study are third-semester students of the Special Education Study Program of the Teaching and Education Faculty, Lambung Mangkurat University in Banjarmasin in which there are students with needs. The third stage is the tryout, which is to disseminate the attitude scale of regular students to students with special needs carried out on regular students in the Special Education Study Program of Lambung Mangkurat University, Banjarmasin, as many as 118 respondents have calculated their validity and relativity. The fourth stage is the implementation of the research after it is known that the measuring instrument has been tested for reliability and its validity is divided into research subjects according to the characteristics that have been determined. The fifth stage is the analytical method used in the study is the normality test that uses the Kolmogorov Smirnov Test to determine the distribution of data that is normal or not. This research in categorizing subjects who have psychological well-being categories tend to be high and low by using a single sample test (T-test) assisted with the SPSS for windows program.

\section{RESULT}

The results of the research data obtained from 68 research subjects or regular students, the researcher can determine high, medium and low scores on the attitude variables of regular students towards students with special needs as shown in the tscore calculation table of regular student attitudes towards students with special needs.

TABLE I. ONE-SAMPLE STATISTICS

\begin{tabular}{|l|l|l|l|l|}
\hline & \multicolumn{1}{|c|}{$\mathbf{N}$} & \multicolumn{1}{|c|}{ Mean } & $\begin{array}{c}\text { Std. } \\
\text { Deviation }\end{array}$ & $\begin{array}{c}\text { Std. Error } \\
\text { Mean }\end{array}$ \\
\hline $\begin{array}{l}\text { The attitude } \\
\text { of regular } \\
\text { students }\end{array}$ & 68 & 105.47 & 8.038 & .975 \\
\hline
\end{tabular}

Table 1 shows that the attitude of regular students with a standard deviation of 8.038. The number of respondents taken was 68 subjects or regular students with a significant 0,000 .

TABLE II. ONE-SAMPLE TEST

\begin{tabular}{|l|c|c|c|c|}
\hline & \multicolumn{4}{|c|}{ Test Value = 0 } \\
\cline { 2 - 5 } & $\boldsymbol{T}$ & $\boldsymbol{D f}$ & Sig. (2-tailed) & Mean Difference \\
\hline $\begin{array}{l}\text { Total Regular } \\
\begin{array}{l}\text { Student Scale } \\
\text { of Attitude }\end{array}\end{array}$ & 108,201 & 67 &, 000 & 105,471 \\
\hline
\end{tabular}

Table 2 shows the test results of the $\mathrm{t}$ count $=108.201$. $\mathrm{T}$ table is obtained with $\mathrm{df}=67$, sig $5 \%(1$ tailed $)=1.667$. Because - $t$ table < from $t$ counts $(1.667<108.201)$. It shows that there is a positive relationship between the attitude of regular students towards students with special needs. 
TABLE III. ONE-SAMPLE TEST

\begin{tabular}{|c|c|c|}
\hline & \multicolumn{2}{|c|}{ Test Value $=0$} \\
\hline & 95\% Confidence & he Difference \\
\hline & Lower & Upper \\
\hline $\begin{array}{l}\text { Total Regular Student } \\
\text { Scale of Attitude }\end{array}$ & 103,52 & 107,42 \\
\hline
\end{tabular}

Table 3 shows that the attitude of regular students towards students with special needs at intervals $(95 \%)$, the value of 103.52 states that the attitude of regular students towards students with special needs is low and the score of 107.42 states that the attitude of regular students to students with special needs is high.

TABLE IV. ONE-SAMPLE KOLMOGOROV-SMinOV TEST

\begin{tabular}{|l|l|l|}
\hline \multicolumn{2}{|l|}{} & \multicolumn{1}{|c|}{$\begin{array}{c}\text { Total Regular } \\
\text { Student Scale of } \\
\text { Attitude }\end{array}$} \\
\hline N & Mean & 68 \\
\hline $\begin{array}{l}\text { Normal } \\
\text { Parameters a,b }\end{array}$ & 105,47 \\
\hline \multicolumn{1}{|l|}{ Extreme } & Absolute \\
Differences & Positive & 8,038 \\
\hline & Negative &, 121 \\
\hline $\begin{array}{l}\text { Kolmogorov- } \\
\text { Smirnov Z }\end{array}$ & &, 121 \\
\hline $\begin{array}{l}\text { Asymp. Sig. (2- } \\
\text { Tailed) }\end{array}$ & &,- 083 \\
\hline
\end{tabular}

Table 4 shows that the results of the data normality test showed that the Kol-Smirnov value was 0.996 , so it can be concluded that the data is normally distributed.

\section{DISCUSSION}

The research that has been conducted aims to determine the attitude of regular students to students with special needs. The results of the analysis show that there is a positive relationship between the attitudes of regular students to students with special needs in the Special Education Study Program of the Teaching and Education Faculty of Lambung Mangkurat University in Banjarmasin.

Attitudes in the views of [34] and [35] are the views or readiness of a person in acting, both in positive and negative forms. When someone positively responds to an object, the tendency of the behavior that arises is to approach, like, and raise hopes for a particular object. The attitude referred to in this study is the attitude of regular students to students with special needs regarding the physical condition of students with special needs, intellectuals and social-emotional conditions of students with special needs.

The attitude that arises from regular students towards students with special needs is what is seen and felt by regular students towards the limitations of students with special needs both physical, social-emotional and intelligence. This is a regular student who can show an attitude in the form of positive or negative attitudes. Positive attitudes that exist in regular students are regular students who tend to accept the presence of students with special needs with some shortcomings both physically, socially-emotionally and intelligently so that when students with special needs experience difficulties. Regular students will always be willing to help and care for the shortcomings of students with needs special. Conversely, if the attitude that exists in regular students is negative towards students with special needs, the regular students will refuse and cannot accept students with special needs with their physical, socio-emotional and intellectual deficiencies so that what they do is avoid and refuse in their social environment.

The subjects in this study were regular students in the Special Education Study Program of the Teaching and Education Faculty of Lambung Mangkurat University in Banjarmasin, regular students would interact with students with special needs on campus.

The findings of this study illustrate that of 68 research subjects or students, 22 subjects $(32.35 \%)$ had a positive attitude towards students with special needs and 46 subjects $(67.64 \%)$ of regular students had a negative attitude towards students with needs special.

Thus, it can be described that only a small percentage of regular students have a more positive attitude towards students with special needs. This is as explained earlier that the attitude of regular students to students with special needs that the view of regular students both male and female in deciding on a behavior regarding knowledge about students with special needs, the belief in individual differences in students with special needs, views on students with special needs, feelings of regular students towards students with special needs, willingness to be motivators for students with special needs in learning, tolerance for students with special needs, ready to be role models for students with special needs, willing to establish communication with students with special needs and willing to learn to teach students with special needs in learning.

According to the Theory of Reasoned Action, between the variables of attitude and behavior (action), there are variables that lead to them, namely intent (disposition). A person who will carry out an action is based on a specific purpose. This theory places attitudes in a central place in relation to human action, attitude is said to be a function of belief. Someone who believes that the action to be taken as a positive impact on him will be inclined to take action. Likewise, the opposite, if it is believed that the action to be taken will have a negative impact on him/her, is refusing to take action [5].

The relationship of student lecturers, students, and even members of the campus community as a whole should be colored by mutual respect and the spirit of working together to achieve good goals. An incompatible relationship that is full of conflict and suspicion is unlikely to form a positive attitude towards the values developed [5].

\section{CONCLUSION}

The results of the study conducted on regular students in the Special Education Study Program of the Faculty of Teacher Training and Teacher Training at Lambung 
Mangkurat University in Banjarmasin showed that the hypothesis was accepted because there was a very significant effect on the attitude of regular students.

Further researcher is expected to conduct a study by connecting this topic with other variables or conduct research with experimental research models so that researchers can become direct participants in following all activities carried out by students with special needs with regular students. Furthermore, the data obtained will be maximized and will be better by considering the condition of students with special needs with regular students in other study programs at the University of Lambung Mangkurat in Banjarmasin.

\section{REFERENCES}

[1] L. G. Otaya, "Urgensi Sikap Mahasiswa Menilai Kemampuan Diri dalam Belajar melalui Asesmen Diri (Self-Assessment)," Jurnal Manajemen Pendidikan Islam, vol. 3, no. 1, pp. 58-67, Feb. 2015.

[2] F. Mangunsong, Psikologi dan Pendidikan Anak Berkebutuhan Khusus Jilid I. Depok: LPSP3 UI, 2014.

[3] D. P. Hallahan, J. M. Kauffman, and P. G. Pullen, Exceptional Children : an Introduction to Special Education, 11th ed. Boston: Allyn \& Bacon, 2009.

[4] D. O. Sears, Social Psikologi Sosial Jilid 1, 5th ed. Jakarta: Erlangga, 1985.

[5] D. Zuchdi, "Pembentukan sikap," Cakrawala Pendidikan, no. 3, Nov. 1995.

[6] U. Hasanah and Y. Nurhamida, "Sikap Siswa Reguler Terhadap Siswa Berkebutuhan Khusus dan Kecenderungan Bullying Di Kelas Inklusi," UNISIA, vol. 37, no. 82, 2018 .

[7] F. Hanurawan, "Sikap Mahasiswa Penggunaan Diskusi Isu-isu Kontoversial,” Jurnal Ilmu Pendidikan, vol. 18, no. 2, pp. 135-141, Dec. 2012.

[8] S. Putri, "The Relation between Konwledge and Attitude of Coed With Treatment Action of Reproductive Organ in Academy Midwifery International of Pekanbaru," Jurnal Kesehatan Komunitas, vol. 1, no. 4 May 2012.

[9] M. K. Akinsola \& F. B. Olowojaiye, "Teacher Intructional Methods and Student Attitudes Towards Mathematics," International Electronic Journal of Mathematics Education, vol. 3, no. 1, Feb. 2008.

[10] A. Astalini, D. A. Kurniawan, A. Susanti, and M. Maison, "Sikap Mahasiswa Pendidikan Fisika Pada Mata Kuliah Fisika Matematika III Universitas Jambi,” Jurnal Pendidikan IPA Indonesia.

[11] N. Nuhamsyah, "Pengaruh Edukasi terhadap Perubahan Pengetahuan dan Sikap Mahasiswa tentang Triad Kesehatan Reproduksi Remaja (KRR) di Fakultas Ilmu Sosial dan Ekonomi Universitas Respati, Yogyakarta,” Jurnal Keperawatan Respati, vol. 2, no. 2, Sep. 2005.

[12] A. Sobur, Psikologi Umum dalam Lintasan Sejarah. Bandung: Pustaka Setia, 2013
[13] S. Azwar, Sikap Manusia dan Teori Pengukurannya, 2nd ed. Yogyakarta: Pustaka Pelajar, 2010.

[14] S. Azwar, Sikap Manusia dan Teori Pengukurannya, 2nd ed. Yogyakarta: Pustaka Pelajar, 2015.

[15] J. Mercer and D. Clayton, Psikologi Sosial. Jakarta: Penerbit Erlangga, 2012.

[16] B. Walgito, Psikologi Sosial (Suatu Pengantar), 4th ed. Yogyakarta: Andi Publishing, 2003.

[17] A. Ahmadi, Sosiologi Pendidikan. Jakarta: PT Rieneka Cipta, 1991.

[18] D. Vardiansyah, Filsafat Ilmu Komunikasi: Suatu Pengantar. Jakarta: Indeks, 2008.

[19] S. Surajiyo, Ilmu Filsafat Suatu Pengantar. Jakarta: Bumi Aksara, 2008.

[20] F. L. Rahmi and K. Arditya, "Hubungan Pengetahuan dengan Sikap terhadap Operasi Katarak pada Pasien Katarak Senilis di RSUP Dr. Kariadi Semarang," Indonesian Journal of Public Health, vol. 4, no. 1, 2007.

[21] W. A. Gerungan, Psikologi Sosial. Bandung: Refika Aditama, 2002.

[22] C. Permana, "Hubungan antara Kecerdasan Emosi dengan Sikap terhadap Tawuran pada Remaja," Thesis, Universitas Gunadarma, Depok, 2014. Available: http://publication.gunadarma.ac.id/ [Accessed September 1, 2018]

[23] M. Fadli and A. Djamhuri. "Pengaruh Kecerdasan Emosional, Kecerdasan Spiritual, Dan Kecerdasan Sosial Terhadap Sikap Etis Mahasiswa Akuntansi (Studi pada Universitas Negeri di Kota Malang)," Jurnal Ilmiah Mahasiswa FEB, vol. 2, no. 2, 2014. Available: http://jimfeb.ub.ac.id/ [Accessed September 1, 2018]

[24] G. Yukl, Kepemimpinan dalam Organisasi, 5th ed. Jakarta: Indeks, 2010 .

[25] M. Sutrisno and H. Putranto, Teori-Teori Kebudayaan.. Yogyakarta: Kanisius, 2005.

[26] A. Fanani, Kamus Istilah Populer. Yogyakarta: Mitra Pelajar.

[27] J. P. Chaplin, Kamus Lengkap Psikologi. Jakarta: Raja Grafindo Persada, 2006.

[28] D. Kustawan, Pendidikan Inklusif dan Upaya Implementasinya. Jakarta: Luxima Metro Media, 2012

[29] M. T. Illahi, Pendidikan Inklusif: Konsep dan Aplikasi. Jogjakarta: ArRuzz Media, 2013.

[30] B. Delphie, Pembelajaran Tuna Grahita. Bandung: Refika Aditama, 2006

[31] T. S. Somantri, Psikologi Anak Luar Biasa. Bandung: Refika Aditama, 2012

[32] S. Arikunto, Prosedur Penelitian: Suatu Pendekatan Praktik, 6th ed. Jakarta: PT Rineka Cipta, 2006.

[33] D. Prayitno, Buku Saku Analisis Statistika Data SPSS. Jakarta: PT. Buku Seru, 2011.

[34] T. Tresvi \& Respati W. S. "Sikap Siswa Kelas X SMK Y Tangerang terhadap Bullying," Jurnal Universitas Surabaya, vol. 3, no. 1, 2012.

[35] A. Siregar, "Sikap dan Perilaku Siswa Kelompok Etnis Keturunan Cina dalam Asimilasi Kebudayaan,” Doctoral Thesis, Program Pasca Sarjana IKIP Jakarta, Yogyakarta, 1992 